https://ejournal.unperba.ac.id/index.php/pijeb

\title{
DETERMINATION EMOTIONAL OF QUOTIENT, SPIRITUAL QUOTIENT, ADVERSITY QUOTIENT AND SPIRITUAL QUOTIENT STRIVE AGAINST JASABOGA BUSINESS SUCCESS
}

\author{
Sri Endah Nurhayati ${ }^{1,2}$, Ratih Hurriyati ${ }^{3}$ Puspo Dewi Dirgantari ${ }^{4}$ \\ ${ }^{1,3,4}$ Universitas Pendidikan Indonesia \\ ${ }^{2}$ Akademi Tata Boga Bandung \\ Email.ssienadahn@gmail.com
}

\begin{abstract}
Culinary business competition is getting tighter in the era of globalization as it is today requires companies to have good human resources and qualified for business success and achieving corporate goals. The improvement of technological advances in this ever-evolving age makes every employee must have adversity quotient, emotional quotient, spiritual quotient and SQ strive. the purpose of this study is to analyze the emotional determination of quotient, spiritual quotient, adversity quotient and SQ strives towards the success of the food service business. The population in this study is all restaurant owners in Bandung. Purposive sampling techniques as many as 67 people. The results showed both partial and simultaneous emotional quotient, spiritual quotient, adversity quotient and SQ seek to have a significant effect on business success.
\end{abstract}

Kata Kunci: emosional quotient, spiritual quotient, adversity quotient, SQ, Success

\section{Introduction}

Human resources (HR) is an important asset in the company. The success of the company can not be separated from the human resources owned by the company, to achieve the company's goals, the company needs human resources that are qualified. Globalization makes companies compete with each other so that companies must continue to make changes by improving technology and quality of service, in achieving the company's goals requires the best business success of the resources that the company has. As stated by Salleh (2005) that Business Success is determined by individuals, organizations, environments, SQ, skill levels, intelligence and response. Human resources (HR) are a very important factor in a company and human resources are used to organize the company so that the company's goals can be achieved.

This human resource factor is an element that must be considered by companies, especially when the era of free trade begins, where the climate of competition is very different. Every company should be able to work more efficiently, effectively and productively. High AQ levels will spur each company to maintain its survival. Human resources are seen as the determining aspect because it is in their hands that all innovations will be made in an effort to realize the company's goals. Culinary business competition is getting tighter in the era of globalization as it is today requires companies to have good human resources and qualified for business success and achieving corporate goals. The improvement of technological advances in this ever-evolving age makes every employee must have adversity quotient, emotional quotient, spiritual quotient and SQ strive.

Some research on adversity quotient, emotional quotient, spiritual quotient has been done with many diverse results. Variable adversity quotient, emotional 
quotient, spiritual quotient and SQ seek to be linked to the Variable Success Attempt. Therefore the author tries to connect the variable with the success of the business, considering that not a few food service companies are maturing as a result of intense competition.

\section{LITERATURE REVIEW}

Every organization or agency to achieve optimal business success every employee must have the ability to find solutions to every problem faced and be able to solve them. In human intelligence there are three things that must be owned by each individual, namely emotional intelligence, spiritual intelligence and having Adversity Quotient so that each individual is able to control themselves in a better direction and be able to provide the best Business Success in which a person performs his daily activities. By having these three intelligences, every human being will have good control of life so that everything is done based on a sense of sincerity and gives success to the best business in which a person is active Ginanjar $(2009 ; 11)$.

Emotional intelligence can also be interpreted as mental abilities that help us control and understand the feelings of us and others that lead to the ability to regulate those feelings. Emotional intelligence is a new discourse observed dancing, people began to know so much of its role in determining success. In maintaining a life today requires a variety of skills that are not taught in school. How to establish a good EQ with customers, how to maintain revenue without offending others, patience stealing opportunities in marketing products, to tenacity to bounce back when experiencing a fall. All of them require ahmad's excellent emotional processing skills $(2005 ; 87)$. If an employee is able to manage his emotions in completing each job then the employee will be able to provide good work results and can improve the Success of the Business in which the employee works.

Spiritual intelligence is an inspired intelligence, inspired drive and effectiveness, theis-ness or divine passion in which we all belong." According to Ginanjar $(2009 ; 13)$ in his book ESQ, "Spiritual intelligence is the ability to give spiritual meaning to thoughts, behaviors and activities, and to be principled only to God." The spiritual quotient (SQ) is a view or tendency to react to interpret every behavior and activity as worship and the ability to put our behavior and life in context and only because Allah SWT so that it can be applied to daily life. With the spiritual intelligence possessed by an employee, every activity in the workplace will run correctly because the employee feels supervised by god the creator so that it will not commit violations related to his work. Spritual intelligence owned by an employee will be able to increase the success of his business because the employee assumes that the work done is an answer or mandate that must be done properly and provide optimal Business Success in the place where the employee is active.

Adversity quotient is the ability of a person to use his intelligence to direct, change his way of thinking and actions when facing obstacles and difficulties that can afflict him. Ginanjar (2009; 13) defines adversity quotient succinctly, i.e. as a person's ability to deal with problems. Some of the above definitions are quite diverse, there is a focus or pressure point, namely the ability that a person has, both physical and psychic in dealing with problems or problems that are being experienced. If an employee has adversity quotient ability then the way of thinking owned by an employee only provides the best work results by providing good business success so that every job given by the leadership can run effectively according to the planned objectives. In addition, another important thing is SQ trying. Given the importance of $\mathrm{SQ}$, the management's concern about the problem of employee SQ in work is to do business by giving SQ to employees in the company through a certain series of businesses in accordance with company policy, so that SQ employees in work will be maintained. To meSQ employees, company 
leaders must know the motives and SQ desired by the employees. One thing that must be understood is that people want to work because they want to meet their needs, both conscious needs and unwitting needs, material or non-material, physical or spiritual needs.

Based on the description above, the framework of this research concept is:

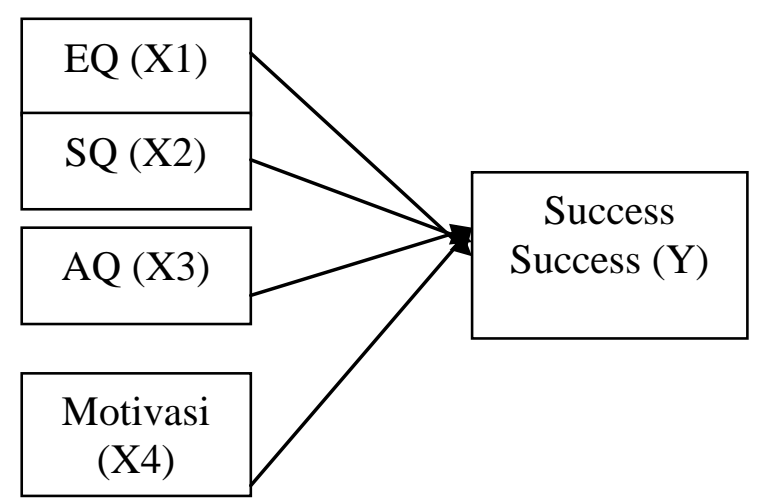

Figure 1

Frame of Research

\section{RESEARCH METHODS}

This type of research is Explanatory Research which explains the relationship between variables of this research through hypothesis testing. In this study, information was collected from respondents through the use of questionnaires with analysis units are restaurant owners in The City of Bandung. Population is the entire subject of research or individuals to which the results of the study will be valid or enforced, and the characteristics will be measured. The samples in this study are representatives of the population to be studied. Sampling techniques using purposive sampling and obtained as many as 67 people. Data analysis using regression analysis aims to analyze the magnitude of the influence of free variables (independent) on bound variables (dependents). Double regression analysis is used to predict how the state (ups and downs) of dependent variables, when two or more independent variables as predictor factors are manipulated (scaled down in value). A bound variable (dependent) is a variable that we want to guess, denoted by the letter Y. A free variable (independent) is a variable used to guess dependent variables, denoted by the letter X.

\section{RESULTS AND DISCUSSION}

\section{The Influence of EQ (X1) on Business Success (Y)}

Based on the results of linear regression testing of $\mathrm{R}$ (correlation) value and determination coefficient (R2) used as an analysis tool to show the magnitude of contribution of independent variables (X1) can explain dependent variables (Y) obtained $\mathrm{R}$ value of 0.800 which indicates that there is a strong influence of EQ on Business Success. Furthermore, the value of coefficient of determination (R2) of 0.639 this means that $63.9 \%$ of Business Success variables are influenced by EQ. Therefore it can be described partially as follows:

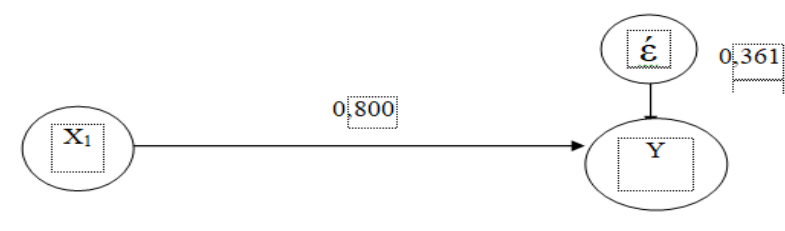

Figure 1

The Influence of Variable X1 on Variable $Y$

To partially test the hypothesis obtained a calculated $\mathrm{t}$ value of 10,735 > t table $(\mathrm{df}=\mathrm{n}-2 ; \alpha 5 \%) 1.67$ or a sig value of $0.000<0.05$ thus it can be said that EQ, has a significant effect on Business Success.

\section{The Influence of SQ (X1) on Business Success (Y)}

Berdasarkan hasil perhitungan diperoleh hasil sebagai berikut :

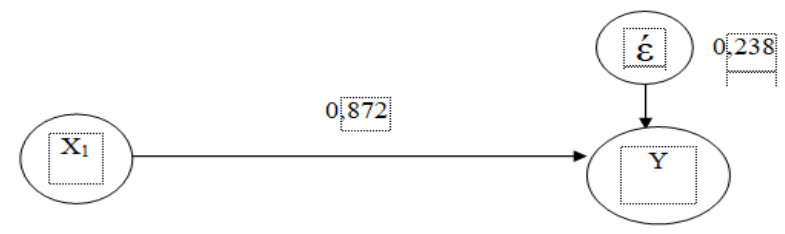

Figure 2

The Influence of Variable X2 on Variable $Y$

To partially test the hypothesis obtained a calculated $\mathrm{t}$ value of 11,542 > $\mathrm{t}$ table $(\mathrm{df}=\mathrm{n}-2 ; \alpha 5 \%) 1.67$ or a sig value of 
$0.000<0.05$ thus it can be said that SQ has a significant effect on business success.

\section{The Influence of AQ (X3) on Business Success (Y)}

Based on the results of the calculation obtained the following results:

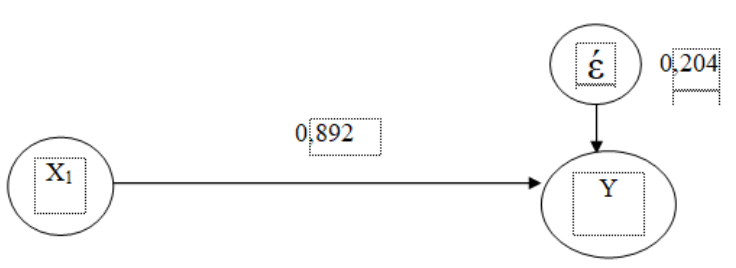

Figure 3

The Influence of Variable X3 on Variable $Y$

To partially test the hypothesis obtained a calculated $\mathrm{t}$ value of 15,917 > t table $(\mathrm{df}=\mathrm{n}-2 ; \alpha 5 \%) 1.67$ or a sig value of $0.000<0.05$ thus it can be said that AQ has a significant effect on business success.

4. The Influence of Attempting to be motivated (X3) on Business Success (Y)

Based on the results of the calculation obtained the following results:

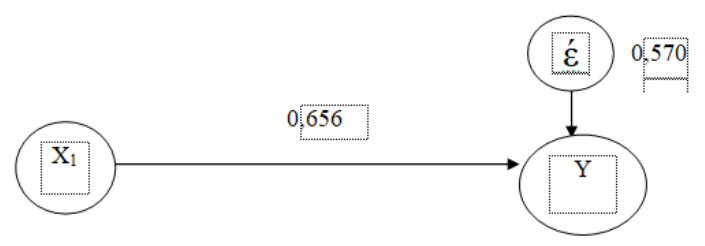

Figure 3

The Influence of Variable X4 on Variable $Y$

To partially test the hypothesis obtained a calculated $t$ value of 7,004 $>\mathrm{t}$ table $(\mathrm{df}=\mathrm{n}$ $2 ; \alpha 5 \%) 1.67$ or a sig value of $0.000<0.05$ thus it can be said that the motivation of trying to have a significant effect on business success.

Based on the calculation result obtained the regression equation is as follows:
Table 1

Multiple Correlation Analysis Results

\begin{tabular}{|l|r|r|r|r|r|}
\hline Model & \multicolumn{2}{|c|}{$\begin{array}{c}\text { Unstandardized } \\
\text { Coefficients }\end{array}$} & $\begin{array}{c}\text { Standardized } \\
\text { Coefficients }\end{array}$ & $\mathrm{t}$ & Sig. \\
\cline { 2 - 6 } & \multicolumn{1}{|c|}{$\mathrm{B}$} & $\begin{array}{c}\text { Std. } \\
\text { Error }\end{array}$ & \multicolumn{1}{c|}{ Beta } & & \\
\hline (Constant) & 1.119 & 1.945 & & .575 & .567 \\
EQ & .183 & .082 & .174 & 2.245 & .028 \\
SQ & .321 & .067 & .348 & 4.762 & .000 \\
AQ & .333 & .091 & .375 & 3.654 & .001 \\
Motivated & .217 & .082 & .169 & 2.650 & .010 \\
\hline
\end{tabular}

Based on the table can be created mathematically regression equation as follows:

$\mathrm{Y}=\mathrm{a}+\mathrm{b}_{1} \mathrm{X} 1+\mathrm{b}_{2} \mathrm{X} 2+\mathrm{b}_{3} \mathrm{X} 3+\mathrm{b}_{4} \mathrm{X} 4$

$\mathrm{Y}=1,119+0,183 \mathrm{X} 1+0,321 \mathrm{X} 1+0,333 \mathrm{X} 3$. $+0,217 \mathrm{X} 4$

Artinya setiap kenaikan skor EQ, SQ, AQ dan motivasi berusaha akan meningkatkan Keberhasilan Usaha. Nilai signifikasi dari variabel EQ adalah 0,028, variabel SQ adalah 0,000 , variabel AQ adalah 0,001 dan variabel motivasi berusaha adalah 0,010 Karena nilai signifikasi dari variabel-variabel tersebut lebih rendah dari tingkat signifikasi $\alpha=0,05(5 \%)$ berarti variabel variabel $E Q$, variabel $A Q$, variable SQ dan variable motivasi berusaha secara bersama-sama berpengaruh terhadap Keberhasilan Usaha.

\section{Discussion}

\section{Analysis of the Impluence of EQ on Business Success}

The results showed that EQ simltan influenced the success of the business. Emotional stress often doesn't get a reasonable portion as a predictor of performance, even tends to be marginalized. Emotional intelligence problems are left alone, without coaching and management. As a result many employees are weak in emotional intelligence. The problem of weak emotional intelligence is characterized by the behavior of employees who like to be late in the office, go home early, use work hours and office equipment for personal benefit, irritable when facing problems or reprimanded by superiors, and others similar behavior. The results of descriptive statistical 
analysis show that in general the condition of emotional intelligence and business success in the food service business is relatively good. Meanwhile, from the results of hypothesis testing using inferential statistics known emotional intelligence has a positive and significant influence on employee performance. These results show that the better the employee's emotional intelligence will have implications for the employee's improved performance, and on the contrary the worse the employee's emotional intelligence, will result in decreased employee performance.

\section{Analysis of the Impluence of $S Q$ on Business Success}

The results showed that SQ had an effect on business success. Referring to Maslow's theory of motivation, spiritual intelligence is related to self-actualization or fulfillment of life's goals, which is the highest level of motivation. High spiritual intelligence is characterized by the growth and transformation of one's self, the achievement of a balanced life between career/work and personal/family, as well as the presence of feelings of joy and satisfaction manifested in the form of producing positive contributions and sharing happiness to the work environment and can improve one's performance where he performs work activities. SQ although it contains the word spiritual is not always related to belief or religion. SQ is more about people's needs and ability to find meaning and generate value through the experiences they face. However, some studies show that a person who has a belief or practices religion, generally has a higher level of spiritual intelligence compared to those who do not have faith or do not practice religion

\section{Analysis of the Impluence of $\mathrm{AQ}$ on Business Success}

The results showed that AQ had an effect on business success. Good employee performance is paramount to the company's survival. If a company wants to grow rapidly, it must have human resources that are able to display a good adversity quotient. The performance of employees whose adversity quotient is high and good will make employees more loyal to the organization or company and is expected to have high performance so that the success of the business will be more assured.

Adversity quotient is a science developed since 1997 regarding one's ability to face and overcome difficulties. Stoltz (2000) found that a sense of helplessness (low AQ) can reduce performance, productivity, and motivation. AQ can measure persistence, responsibility, hope, optimism, and stress in a person, in addition AQ can also make a person turn difficulties into opportunities in work. Stoltz (2000) also revealed that there are four AQ indicators, namely control, ownership, reach, and endurance. Therefore, AQ is one of the important components in a person's success.

\section{Analysis of the Impluence of Motivated on Business Success}

The results showed that motivation seeks to influence the success of the business. One thing that must be understood is that people want to work because they want to meet their needs, both conscious needs and unwitting needs, material or nonmaterial, physical or spiritual needs. This motivational giving is many kinds such as the awarding of proper and fair compensation, awarding and so on. This is intended so that whatever the needs of employees can be met and it is expected that the employees can work well and feel happy with all the tasks they take on (Faizal et al., 2019). After employees are happy with their work, employees will respect each other's rights and obligations so that a conducive work atmosphere is created, in the end employees seriously give their best ability in carrying out their duties and responsibilities, and this means that the discipline of work will be shown by the employees, because it is motivated in carrying out their duties in the company.

This result is supported by the Theory of Expentansi, which is expressed by Vroom. Vroom points out "That people will be 
motivated to do certain things to achieve goals if they believe that their actions will lead to achieving those goals"

\section{Conclusion}

EQ, SQ, AQ and motivation to strive both partially and simultaneously have a significant impact on the success of the food service business. In this study there is a limited number of samples that are used have not used the census so that it affects the results of the study. Therefore, it is expected that researchers can then use more samples and add other variables that can affect the business success of employees.

\section{REFERENCES}

Ilyas, Yaslis. 2012. Keberhasilan Usaha, teori, penilaian dan penelitian. Jakarta: Pusat Kajian Ekonomi Kesehatan FKM Universitas Indonesia

Ahmad, Tohardi. 2015. Pemahaman Praktis Manajemen Sumber Daya Manusia. Bandung: Universitas Tanjung Pura, Mandar Maju.

As'ad Mohammad. 2016. Seri Ilmu Sumber Daya Manusia: Psikologi Industri, Edisi IV. Yogyakarta: Liberty

Gibson, M, 2016. Manajemen Sumber Daya Manusia. Cetakan ke dua. Jakarta: Erlangga.

Handoko, T. H., 2016. Manajemen Personalia dan Sumber Daya Manusia. Yogjakarta : BPFE .

Ilyas, Y. 2012. Perencanaan SDM Rumah Sakit: Teori, Metoda, dan Formula. (cetakan pertama). Depok: Pusat Kajian Ekonomi Kesehatan Fakultas Kesehatan Masyarakat -Universitas Indonesia, Jakarta.

Irwady,2013. Penilaian Motivasi berusaha Perawat http://www.scribd.com/doc/3604370

7I Penilaian-Beban-Kerja diakses tanggal 14 Mei 2019.

Cangara, Hafied. 2013. Pengantar Ilmu EQ. Jakarta: PT. RajaGrafindo Persada.

Faizal, R., Sulaeman, M., \& Yulizar, I. (2019). Pengaruh Budaya, Motivasi Kerja Dan Kompetensi Terhadap Kinerja Karyawan. EBA Journal: Journal Economics, Bussines and Accounting, 5(1), 11-21. https://doi.org/10.32492/eba.v5i1.706

Kurniadi, Anwar. 2013. Manajemen Keperawatan dan Prospektifnya: Teori dan Aplikasi. Jakarta: Fakultas Kedokteran Universitas Indonesia

Kusmiati A, Pudjiastuti B, Suptana, P. 2016. Teori Dasar EQ Visual. Jakarta: Djambatan

Mangkunegara. 2013. Evaluasi Keberhasilan Usaha Sumber Daya Manusia, Cetakan Pertama. PT. Refikaditama, Bandung.

Mondy R Wayne. 2018. Manajemen Sumber Daya Manusia. Jakarta: Erlangga

Munandar, 2015.Psikologi Industri dan Organisasi, UI-Press : Jakarta

Rivai, Veithzal \& Jauvani Sagala. 2016. Manajemen Sumber Daya Manusia Untuk Perusahaan Dari Teori ke Praktik. Jakarta: Rajawali Press.

Robin, dan Judge. 2018. Perilaku Organisasi, Jilid 2. Jakarta : Salemba Empat.

Sarminah, Samad, 2018. Sarminah. 2006. Predicting Turnover Intentions: The Case of Malaysian Government Doctors, The Journal of American Academy of Business, Cambridge, Vol.8, No.2, March 
Sulaeman, Maman 2018, The Influence Of Work Culture, Motivation And Compensation To The Perfomance Of Employees In Government, Jurnal eBA Vol. 4 No. 1, Februari 2018.

http://ejournal.undar.ac.id/index.php leba/article/view/540

Wahyuni. Alimudin, 2013. Pengaruh Kompensasi Terhadap Produktivitas Karyawan Pada PT. Bakrie Telecom Area Makassar.

Werner. Jackson, 2010. Pengelolaan Sumber Daya Manusia, Edisi 10, Salemba Empat, Jakarta.

Wibowo, 2012. Manajemen Keberhasilan Usaha, Edisi Kelima, PT.Rajagrafindo Persada Jakarta14240. 